\title{
The Design Of Water-Filled Rubber Dam As An Efficient Innovation In Preventing Tidal Flood (Rob)
}

\author{
Fatchur Roehman ${ }^{1}$, Slamet Imam Wahyudi ${ }^{2}$, M. Faiqun Ni'am ${ }^{3}$ \\ \{fatchurroehman@gmail.com\} \\ Faculty of Engineering, Sultan Agung Islamic University (UNISSULA) Semarang \\ Jl. Raya Kaligawe KM 4 Semarang $50112^{123}$
}

\begin{abstract}
The river water that cannot flow into the sea because the tide comes through the estuary becomes the background of this research. The objectives of this research are, (1) evaluating flood and rob as the existing motion dam's benefit and preparing the closedcircuit water channels for experiments, (2) analyzing the characteristics of the water-filled rubber dam and making its prototype to obtain its material and to utilize it as the efficient technology, (3) conducting stability analysis of the flow in the dam, (4) conducting the simulation of water's elevation and discharge with prototype of the dam in the laboratory. The researchers used variation of dam parameters tested in Civil Engineering Laboratory of UNISSULA Semarang in six months. Testing the physical model with a simulation of several experiments was done to get the calculation of the stability of the water-filled dam and the effective dimension in handling flood and robs.
\end{abstract}

Keywords: water-filled rubber dam, model test, flood and rob prevention.

\section{Introduction}

A rubber dam is one of the new types of motion dam developed in the construction of water built approximately 30 years ago. By using rubber dam, we can save the cost of execution and operation on the width of the span and the height of the dam compared to the fixed dam (concrete construction) and the construction dam (sluice gate and stop log). This type is chosen with the consideration that the water-filled rubber dam has the advantage of being able to adjust the crest elevation of the dam as required. It is more durable than the air-filled rubber dam and eliminates the effect of the $\mathrm{V}$ knotch on the dam body during deflection. [1]

The objectives of this research are (1) evaluating flood and rob disasters as the benefit of the existing motion dam and preparing the closed-circuit water channels for experiments, (2) analyzing the characteristics of the water-filled rubber dam and making the prototype of the water-filled rubber dam to obtain the material of the dam and to utilize as the efficeient technology, (3) conducting stability analysis of the flow that occurs in the model of water-filled rubber dam, (4) conducting the simulation of water's elevation and discharge with prototype of water-filled rubber dam in the laboratory. The main problem formulations studied in this research are (1) how the effectiveness of water-filled rubber dam from the hydraulic aspect is, (2) how the material characteristic of the water filled rubber dam is, (3) how to analyze the stability of the numerical model of the rubber-filled water dam. 


\section{Literature Review}

\subsection{The Definition of Dam}

Dam is a river water construction that aims to raise the river waterfront in Upstream. Another aim is to raise the water level so that it can be used to irrigate the rice fields (irrigation). The motion dam is a dam with a non-steady crest elevation, or equipped with a door/regulator so it can adjust the water level. [2]. The regulator of the rubber dam can be inflated and deflated as needed by adding or reducing the filling. [3] The filling of the rubber dam can be water or air according to the normative reference of SNI 03-2415-1991 on the method of calculating flood discharge, SNI 03-1724-1989 on hydrological and hydraulic planning guidelines for river buildings, and SNI 03-2401-1991 on the planning of dam. [4].

\subsection{Basic Planning}

Hydraulically, the rubber dam must meet the provisions that are capable to serve the planned water level and open automatically if there is a flood that exceeds a certain limit, to bend that serves to withstand saltwater intrusion, to be safe against the scouring of river basins due to water logged energy, and to be safe against disruption due to water currents and transportable solids. [5]. The height of the rubber dam generally does not exceed $5 \mathrm{~m}$, with the consideration that the construction of a rubber dam with a height $>5 \mathrm{~m}$ is not efficient anymore. Based on the layout of an anchor, the rubber dam can be distinguished into (1) a single line anchorage dam which can only be used for one-way flow which means it can only withstand the flow from the upstream and is usually used in spillways and upstream rivers, (2) a doube line anchorage dam which can be used for one-way and two-way flow. This rubber dam can hold water at high upstream water level, low downstream water level, and vice versa. This rubber dam can be used in coastal areas.

\subsection{Body Planning of Dam}

The rubber material is an elastic, strong, hard and durable rubber material. Generally, the rubber material used has the hardness specification of abrasion test using the $\mathrm{H} 18$ method with a $1 \mathrm{~kg}$ loads at a spin of 1000 times, and does not exceed $0.8 \mathrm{~m} 3 / \mathrm{mile}$ with the tensile strength at normal temperature of $\geq 150 \mathrm{~kg} / \mathrm{cm}^{2}$ and tensile strength at a temperature of $1000 \geq 120 \mathrm{~kg} / \mathrm{cm} 2$. The rubber material is strengthened with nylon yarn arrangement that gives the tensile strength as needed to compress the force. Basic materials of rubber are ethylene propylene diene monomer (EPDM) and rubber chloroprene (CR). To remove scratches by sharp objects, the skin with ceramic material can be made. The thickness of the rubber sheet is determined by the thickness of the nylon yarn arrangement plus the cover layer on both sides to ensure air tightness. The outside cover layer is thicker for the safety against the scratches or abrasion by hard objects. It requires a layer thickness of about $3 \mathrm{~mm}$ inside and outside. The rubber tube clamping system on the foundation is a clamp that uses armored steel. For a low dam with $\mathrm{H} \leq 1.00 \mathrm{~m}$, there must be a single armature, while for $\mathrm{H}>1.00 \mathrm{~m}$, double armature is used. Dams that affect the tides of sea water always use double armature.

Rubber dam data in Demak Regency that serves for flood and rob prevention can be seen as follows: (1) Welahan Bum rubber dam in Gerdu village, Pecangaan sub-district, Jepara regency on River Kali Bum (East of Serang River) with $127.50 \mathrm{~m} 2 \times 30 \mathrm{~m}$ and $3 \mathrm{~m}$ in height for 2,628,319 m3 capacity. (2) Buko rubber dam, Demak regency on Jalan Raya Buko-Kenduren, 
Wedung sub-district, Demak regency at Kali Kumpulan with $42 \mathrm{~m}$ in width and $2.70 \mathrm{~m}$ in height for $600,000 \mathrm{~m}^{3}$ capacity. (3) Kali Jajar rubber dam of Demak regency in Jatirogo village, Bonang district, Demak regency in Kali Jajar river of Demak district with $75.5 \mathrm{~m}$ wide in width $(2 \times 37,75 \mathrm{~m})$ and $3 \mathrm{~m}$ in height, full $5.5 \mathrm{~m}$ in width, thick rubber of $10.5 \mathrm{~mm}$ for a capacity of $1.450 .000 \mathrm{~m}^{3}$.

\section{Research Methods}

Variations of dam parameters were tested in Civil Engineering Laboratory of Sultan Agung Islamic University (UNISSULA) Semarang with a period of six months. Testing the physical model with a simulation of several experiments was done to get the calculation of the stability of the water-filled dam and the effective dimension in handling flood and robs. [6]. The objects in this study were to calculate the water discharge, the dimension of the dam, the stability of the dam with the loading behavior in the water-filled dam quickly and correctly. The required data include drawing dimension plan and construction of water-filled rubber dam, water discharge, [7]. The stability of water-filled rubber dam, equation of hydraulic formulas, cost budget plan, materials and equipment, DED guidance reference of water-filled dam. The technical specifications of dam body used are:

\subsection{Flow Chart of Research}

The method used in this research began by understanding the background of research and preparation phase by looking for the literature review of libraries, journals, proceedings and project data. [8]. The step was continued with understanding the purpose of research as well as the formulation of problems and determination of variables, so that the model hypothesis that will be simulated to the hydraulics laboratory in the study of water-filled rubber dam was decided. The next step was testing the installation stage of the instrument and the prototype, so the debit elevation can be simulated as well as the simulation of the dam's inflation and deflation to the treatment characteristics in receiving the load from upstream and downstream in the form of tidal water. [9]. Then, the next step was doing the analysis of test results. If the results are not appropriate, re-research on the stages of determination of variables has to be done and if they are appropriate, the next stage, data analysis, is conducted. The final stages were presentation of the results of research and preparation of the report and then the stage.

\section{Results And Discussion}

\subsection{The comparison of Dams from Facet Structure between the Water-Filled Rubber Dams and Air-Filled Dam}

Dam's material differenciates from filling media which are water and air. According to the system, the works of how the dam inflates and deflates between water and air media are almost the same. The water or air hole is a hole for filling and discharging water or air in a rubber tube. Pumps and channels air or water should be provided to inflate the rubber tubes. The pumping of air into the rubber tube should be provided with a water or air pressure controller. Water filler media of this rubber dam is inflated by filling the water into the rubber dam produced by a water 
pump with a fuel motor or an electric motor drive. [10] The characteristic of the rubber dam with water filler is this rubber dam can regulate the upstream water level and water discharge that flows downstream, as long as the dam surface is flat during the inflation and deflation, no $\mathrm{V}$-Shape occurs. The circumference of the surface of the rubber dam is longer and the weight of water is greater than the air, thus it requires a larger ground and a heavy foundation. [11]. With a larger ground, the rubber dam is more stable and can reduce the vibrations caused by the flow of water and wind, free from the influence of air temperature, especially in the tropics, but very dangerous if it is used in cold areas (snow), because the water in the rubber dam gets into the ice, the tensile stress is small because the water pressure outside and inside the rubber dam is almost the same. If at the time of rubber dam deflates and the downstream water level rises, it will slow down the deflation time, and it may need a pump to discharge water in the rubber dam. The water level for the overflow can be up to $50 \%$ of the height of the dam. It requires a pumping station and equips with a sieve and water reservoir. It also requires larger diameter pipes, considering the losses incurred due to the construction and friction losses between the pipe wall and the water.
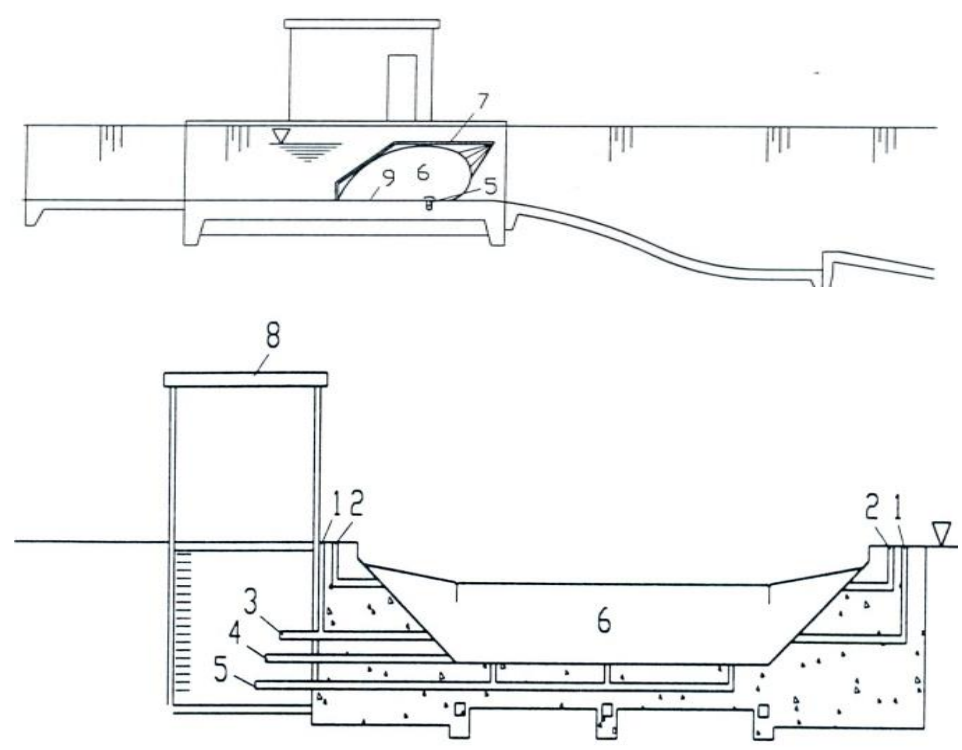

1. Overflow safety pipe

2. Air drain pipe

3. Upstream water level control pipes

4. Water pressure control pipe in the dam
5. Water supply and outlet pipe

6. Dam's rubber body

7. Wall armature

8. Control house

9. Ground rubber

\subsection{Hydraulic Characteristics}

The rubber dam can elevate the water level by inflating the body of the dam and lower the water level by deflating it. The opening of the dam can be done automatically with the deflection of the rubber tube; its inflation can only be done manually. Hydraulic dam design includes flood elevation of +2.40 and embankment elevation of $+3.40,3.00 \mathrm{~m}$ height of dam, the ground 
elevation of -1.50 , and $30 \mathrm{~m}$ for the width of dam. A drain door with width of $2.0 \mathrm{~m}$, run off capacity of $350.41 \mathrm{~m} 3 / \mathrm{s}$, upstream apron length of $20 \mathrm{~m}$, thick of $0.50 \mathrm{~m}$. The length of downstream apron is $8 \mathrm{~m}$ with the thickness of $0.50 \mathrm{~m}$ and the length of dam's floor is 20 with the thickness of $2.00 \mathrm{~m}$ while the length of pond is $10 \mathrm{~m}$ with the thickness of 1.00 .

\subsection{Pattern of Dam Operation}

In the operation of dam, it is necessary to note that the dam is in good condition and not leaking, the installation of inflating/deflating pump can work well, well-designed instructions and operating patterns are available. The dam operation should be done following the predefined pattern. Operations officers should master the instructions and patterns of rubber dam operation. The maintenance of the rubber dam, especially the rubber, should be done with high intensity, considering the trivial disruption to the rubber causes the dam does not work at all. Equipment for rubber dam operation include 1 (one) set blower with the specification of the pump capacity (blower) is no less than $14 \mathrm{~m}^{3} / \mathrm{min}$, the maximum pressure of $4000 \mathrm{mmaq}$, drive pump in the form of diesel motor, 1 (one) set control/operation panel, 1 (one) set inflating/deflating pipe installation, 1 (one) set valves for operation and safety. The maintenance work is divided into four kinds including periodic inspection to determine the condition of the building, periodic treatment of each component of the dam, repairs done in case of dam damage, and continuous protection to prevent dam damage.[12].

\subsection{Experimental Plan of Water-Filled Rubber Dam Contains Water}

The prototype used in the laboratory is as follows (Fig. 1.):

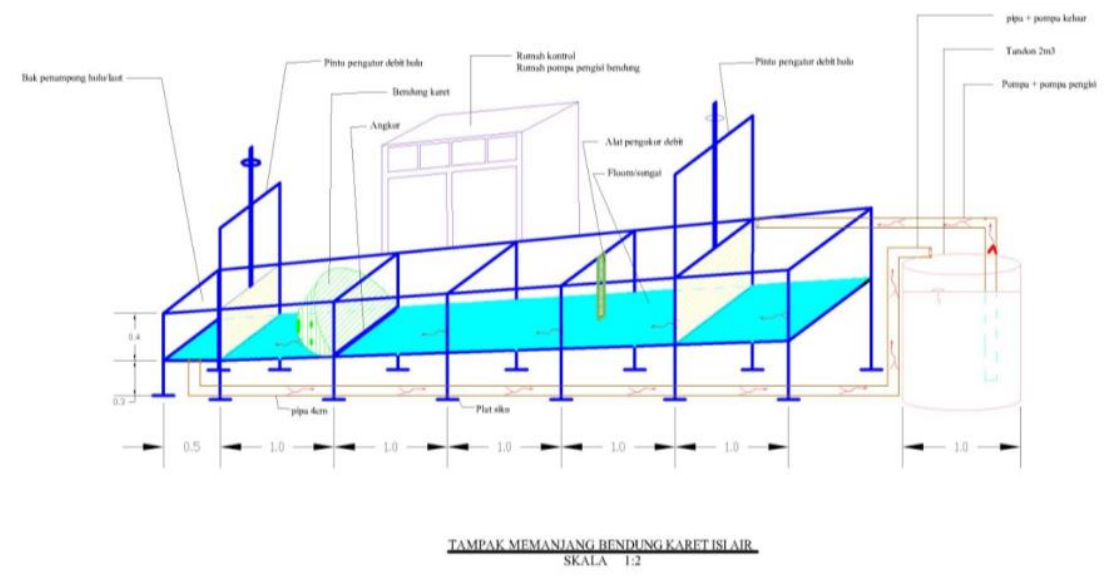

Fig. 1. Prototype of Water-Filled Rubber Dams in Laboratory.

\subsection{Analysis of Experimental Scale}

A good rubber dam has its criteria. It can be developed properly without leakage and deflated automatically and manually on the planned condition. It has a grounding that can be dewatering and easy rubber patching. The dam body is protected from sunburn, for example with a pedestrian bridge. The dam body is safe against public disturbance and river transportation. The 
dam body is resistant to sediment abrasion, safe to water currents and sediment/garbage transport. Hence, the required data are the plan discharge of Q100 which is $305,09 \mathrm{~m} 3 / \mathrm{s}$ with the water-filled dam type, 1 (one) set volume/quantity and the base width of $30 \mathrm{~m}$ and the height of $3 \mathrm{~m}$. The crest elevation of the dam is $+1,50$ and -1.50 for its base elevation. The elevation of downstream water level is -1.20 and the slope of the foundation wall is $1: 1$. The maximum filling/inflation time is no more than 45 minutes as well as the deflation process is no more than 45 minutes. It is controlled manually by clamping system (armature) with double clamping/armature system and pitch max of $200 \mathrm{~mm}$ armature. The material used is ethylene propylene monomer rubber (EPM) or chloroprene rubber as well as the carpet used is the same as the rubber dam. Armature's bolts and nuts use stainless steel (SUS 304). The base plate used is SS 400 galvanized carbon steel and the rubber clamp plate or cover plate uses 500 galvanized FCD cast iron. It has a total of 1-year warranty and 1 (one) set of pumps with the capacity of the pump is not less than $0.20 \mathrm{~m} 3 / \mathrm{s}$ and the head pump head height is adjusted with the installation of the filler pipe. Pump drivers consist of an electric motor, a control/operational panel, the installation of water filling pipe, 1 (one) set of valves for operating and securing with the power supply, and $135 \mathrm{Kva}$ generator as pump drive.

\section{Conclusion And Suggestion}

\subsection{Conclusion}

From the preliminary study for the research, it can be concluded that the selection of materials used for the water-filled rubber dam affects the flow stability pressure. The characteristic of domestic water-filled rubber dam is not easy to obtain in the free market. The planning of waterfilled dam utilizes geo-membrane material as a form of appropriate technology.

\subsection{Suggestions}

In order to use the water-filled rubber dam well, things that should be considered are the calculation of flow stability, the dam's weight itself, and the soil's carrying capacity factor. The study of supporting data factors that burden the river flow on the dam needs to be done in choosing the location of dam's point. It is expected that there are researchers who can develop this method in planning the water-filled rubber dam without causing much damage to the ecosystem of the area around the river. Every option does have its risks, but we must try to minimize the risk so that the balance is maintained.

\section{Acknowledgments}

KEMENRISTEK DIKTI in funding research grants postgraduate 2018, DINAS PSDA Prov. JATENG and BBWS for the data support. All civitas academic of Sultan Fatah Demak University in prayer and support. 


\section{Reference}

[1] V. Yadav, D. Mehta, S. Waikhom, and S. S. Gec, "Suitability of Rubber Dam as a River Water Management Tool," 2015.

[2] S. Ky, J. Martinez, and S. Chhun, "10 - Mechanical Stability of River Banks Submitted to Fluctuations of the Water Level," in Advances in Multi-Physics and Multi-Scale Couplings in GeoEnvironmental Mechanics, 2018.

[3] G. A. Kirchner, "Rubber dam.," J. Am. Dent. Assoc., vol. 144, no. 11, p. 1220, 2013.

[4] I. Buchori, A. Pramitasari, A. Sugiri, M. Maryono, Y. Basuki, and A. W. Sejati, "Adaptation to coastal flooding and inundation: Mitigations and migration pattern in Semarang City, Indonesia," Ocean Coast. Manag., vol. 163, 2018.

[5] J. Hinkel et al., "Coastal flood damage and adaptation costs under 21st century sea-level rise," Proc. Natl. Acad. Sci., vol. 111, no. 9, 2014.

[6] S. Imam Wahyudi, R. Heikoop, H. P. Adi, T. Overgaauw, B. Schipper, and R. Persoon, "Emergency scenarios in the banger polder, semarang city: A case study to identify different emergency scenarios," Water Pract. Technol., vol. 12, no. 3, 2017.

[7] A. Y. Daramola, O. T. Oni, O. Ogundele, and A. Adesanya, "Adaptive capacity and coping response strategies to natural disasters: A study in Nigeria,” Int. J. Disaster Risk Reduct., vol. 15, 2016.

[8] H. P. Adi and S. I. Wahyudi, "Tidal Flood Handling through Community Participation in Drainage Management System ( A case study of the first water board in Indonesia ), Int. J. Integr. Eng. Spec. Issue 2018 Civ. Environ. Eng., vol. 10, pp. 19-23, 2018.

[9] S. Imam Wahyudi, H. Pratiwi Adi, E. Santoso, and R. Heikoop, "Simulating on water storage and pump capacity of ' Kencing ' river polder system in Kudus regency, Central Java, Indonesia," AIP Conf. Proc., vol. 1818, 2017.

[10] S. Hasan and I. Kabir, "Open Access Feasibility of Natore Rubber Dam on Mahanonda River in Bangladesh and its Performance on Irrigation," no. 1, pp. 27-34, 2014.

[11] J.A.E. Ten Vedhuis and F. H.L.R. Clemens, "Uncertainty in risk analysis of urban pluvial flooding: a case study," Water Pract. Technol., vol. 4, no. 1, 2009.

[12] K. Lowery and S. Liapis, "Dynamic analysis of an inflatable dam subjected to a flood," Comput. Mech., vol. 24, no. 1, pp. 52-64, 1999. 